\title{
Russian parliament boosts science funding
}

Moscow. As the US Congress continues to debate where to cut the country's science budget, the Russian parliament has been putting pressure on the administration of President Boris Yeltsin to increase substantially its financial commitment to research in the next financial year.

Last week, the Federation Council - the upper chamber of the Russian Federal Assembly - approved a federal budget pledging to spend a total of 248,000 billion rubles (about US\$60 billion) in 1995. Within this, the council approved a figure of 7,100 billion rubles for the support of science, supporting an amendment added earlier by the lower house, the State Duma, to increase the government's original request of 5,442 billion rubles by 1,700 billion rubles.

The Duma amendment had been proposed by Nikolay Vorontsov, chairman of the science subcommittee of the Duma's Committee for Education, Science and Culture and vice president of the Academy of Natural Sciences, and committee member V. Shevelucha.

In welcoming the Federation Council's approval of the increase over the adminis- tration's request, Vorontsov said that although the 1995 budget as adopted would not resolve the problems faced by science, "it would give it a breath of air enabling it to survive". If the increase were to be met in full, he said, "the tendency of decay will be changed into an increase for the first time for six years".

But supporters of tight budget constraints claim that the bid to provide such a large increase in research funding is irresponsible at a time when the country is facing a massive budget deficit (the total predicted income for next year is only 175,000 billion rubles, leading to an anticipated deficit of 73,000 billion rubles).

Oksana Dmitriyeva, for example, chairwoman of the lower budgetary subcommittee, told the Duma in the debate leading up to last week's vote that the extra 1,700 billion rubles being proposed in a populist amendment to the administration's budget request could not be found, even if all presidential, governmental and parliamentary offices were to be closed down.

Dmitriyeva and others who warn that the deficit can be met only by incurring yet more foreign debt had been supporting a more modest increase of only 400 billion rubles.

In the end, however, the Duma voted to allocate a total of 6,300 billion rubles to research -900 billion rubles more than the initial proposal - with an extra 800 billion rubles "to be made available from additional budget revenue". This refers to a provision in the budget for distributing any unanticipated income; in practice, however, this is unlikely to materialize.

Supporters of this enlarged sum claimed it is intended to counteract the present "chronic underfunding" of Russian science. This year, research and development is due to receive only 0.68 per cent of the country's gross national product (GNP).

But critics point out that even these figures are overoptimistic. Last year, while the government had planned to increase research and development spending to 0.69 per cent of GNP, the real figure was only 0.44 per cent. Thus whether or not President Yeltsin approves the new increase - the final step before it becomes law - many feel that the parliament's wishes are unlikely to materialize in full.

Carl Levitin

\section{Europe cuts its space station bill to win wider support}

Paris. The council of the European Space Agency (ESA), under pressure from its member states to cut costs, last week decided to reduce by almost a half the funding of its planned contribution to the construction of the international space station Alpha.

The council's move will reduce the development costs of ESA's proposed contribution to the station between 1996 and 2000 from ECU3.5 billion (US $\$ 4.6$ billion) to ECU1.8 billion. It is aimed at making the project more acceptable to Europe's space ministers, who will make a final decision on Europe's participation in the project at a meeting in October; both France and Germany had told ESA that they could no longer afford the original cost.

The main victim of the new proposal is the Crew Rescue Vehicle (CRV). This was to have been built by France, and to have cost ECU1.2 billion in development costs between 1996 and 2000. The Apollo-like capsule was to have been mounted on the nose of the new Ariane V launcher, due to make its maiden flight later this year.

ESA's contribution to the station will now be limited to the Columbus Attached Pressurized Module (APM), which will be built by Germany and Italy, and the Automated Transfer Vehicle (ATV), which will be built by France. The latter will ferry freight and fuel from Ariane $\mathrm{V}$ to the station, and nudge the station into its final orbit at a height of $407 \mathrm{~km}$ and an inclination of 51.6 degrees.

The US National Aeronautics and Space
Administration (NASA) has not yet formally agreed that Ariane V can be used to help build the station, in parallel with its own space shuttle. ESA is keen to offer the use of Ariane $\mathrm{V}$ as payment in kind towards its part of the estimated FF7 billion annual running costs of the station. In doing so, it is hoping to avoid the politically sensitive situation of having to ask its cash-strapped member states to pay these running costs in cash.

But ESA officials say that there is now a

\section{IMAGE UNAVAILABLE FOR COPYRIGHT REASONS}

Abandoned hope: originally Ariane V was planned to launch the space plane Hermes. "strong understanding" by the United States that Ariane V will be used. One reason may be that with NASA's budget under heavy pressure at home, Europe's participation is increasingly necessary to ensure the space station's survival.

Indeed, President Bill Clinton wrote to France's president, François Mitterrand, last month, assuring him of his "total personal support" for the station, and asking him for Europe's "permanent participation [in the station], which is essential to its success".

A firm commitment by Europe to the station will have to wait for a meeting of ESA's space ministers to be held in Toulouse, France, in October. But while last week's meeting avoided the thorny issues of how much each member state would pay, the slimmed down proposal "should make everybody happy", says one ESA official.

In response to the council decision, US Representative Bob Walker (Republican, Pennsyvlania), chairman of the House of Representatives Science Committee, said he would like to see ESA's technical position in negotiations between the United States and Russia to be "as strong as possible".

The ESA council also formally agreed at last week's meeting to provide funding that will allow the remote-sensing satellite ERS-1 to remain in operation for several months after the launch of its successor, ERS-2, due in a few weeks' time, providing a unique opportunity to fly the two satellites in tandem.

Declan Butler 